\title{
Transport tax in Russia as a promising tool for the reduction of airborne emissions and the development of the road network
}

\author{
I. Mayburov \& Y. Leontyeva \\ Ural Federal University named after the first President of \\ Russia B.N. Yeltsin, Russia
}

\begin{abstract}
This paper focuses on the fact that Russia is to see an accelerated and unregulated growth of the car fleet, while the development of the road network is seriously lagging behind. The paper looks at the theoretical aspects of the internalization of transport externalities and analyzes negative externalities of car use. It characterizes the key negative impacts that potentially need to be offset through transport tax. It is proved that the impacts are most prominent in areas with a higher rate of car ownership where a large part of the population develops strong automobile dependency. The hypothesis is put forth that the situations differ with regard to positive and negative externalities and, consequently, should determine different conditions for transport tax, the development of the road network and vehicle growth control policies. The model of transport tax that exists now in Russia is analyzed and its key advantages and disadvantages are outlined. This paper provides reasons for a conclusion that the current tax rates in Russia's regions are not aligned with the level of road infrastructure. New goals for the tax reform are proposed: to enhance its fiscal function and assign it a regulatory role. Conceptual provisions of a new transport tax model have been formulated and a differentiation system has been substantiated for territories and tax rates depending on a ratio of positive and negative effects of car use.
\end{abstract}

Keywords: transport tax, emission, road network, motor transport, negative externalities. 


\section{Introduction}

Motor transport plays a very significant role all over the world. The development of motor transport is of particular economic importance to countries with vast territories. For such countries, a big car fleet is an indispensable element of interregional cooperation and labor mobility.

Russia is the largest country on the planet. Motor transport in Russia is the most popular means of shipping in Russia. It accounts for over 75 percent of cargo transportation and 50 percent of passenger transportation.

At the same time, Russia has an average car ownership rate. The number of vehicles per 1,000 population in Russia is three times lower than in the USA and almost two times lower than in France, Japan, Germany and Great Britain.

It is obvious that in a mid-term perspective the gap in the car ownership rates will be narrowing. Russia is going to see an accelerated and unregulated growth of the car fleet. It is possible to say that a true car boom has already started in Russia. Over the past seven years, the number of cars in Russia has grown by over 150 percent, mostly because of increasing private car ownership. As a result, privately owned cars make up 90 percent of traffic, while the share of public transport and trucks does not exceed 10 percent.

These dynamics will turn Russia into the largest auto market in Europe, but might be detrimental to the quality of air in some urbanized regions of the country and lead to a rise in health issue and mortality rate among the local population [1, 2]. The damaging impact of cars on the environment in Russia is estimated at 3.5 billion dollars annually, with the figure rising year-on-year.

Such considerable damage is largely due to the old age and poor environmental performance of the vehicle fleet in Russia. For example, in early 2014 the share of cars aged under five years stood at 28 percent, 22 percent of the fleet was five to ten years old and almost 50 percent were over ten years old. Half of the Russian fleet is Euro-2 and Euro-1 cars, which is very damaging to the environment. The prevalence of older cars in the vehicle fleet has a particularly negative impact on the environment in big Russian cities where car emissions account for 60 to 80 percent of total air pollution.

Additionally, there is an obvious gap between growing car ownership and the development of the road network. The pace of road construction is twice as slow as the growth rate of car ownership [3]. Road funds are short of money. Municipal authorities lack their own sources of funds for road construction.

\section{Theoretical aspects of internalization of motor transport externalities}

As we know, any activity that includes public goods as accompanied by various externalities and internal costs.

Externalities are traditionally understood as factors whose benefits and costs are not reflected in the market price of goods and services, unlike internal costs that are reflected in market prices. Consequently, internal costs are covered 
by car users themselves, while externalities are paid for by the entire society (local community).

Positive externalities are benefits that are enjoyed by a third-party as a result of an activity of another party without any pay from the former. Economic agents are, therefore, willing to pay for benefiting from positive externalities.

Negative externalities are a loss in the welfare of one party resulting from an activity of another party, without there being any compensation for the losing party. In this case, economic agents are prepared to pay for avoiding negative externalities.

At the same time, the market itself is unable to create a system of market-based prices that would encourage producers of negative externalities to reduce their impact, and consumers of positive externalities to pay for the positive external effects. Internalization of externalities make it possible to remedy this inability of the market reflect the occurring effects in pricing. Internalization of externalities is the process of incorporating externalities into the market mechanism of production that provides for their conversion into internal (private) costs that are accounted for in prices. This processes is sometimes referred to as correction of externalities.

The concept of externalities was first developed by Pigou [4]. He theoretically proved that resources are not distributed efficiently in the presence of negative externalities. Consequently, the state has to intervene to solve the problem of internalizing externalities. Such intervention involves imposing a tax that is set equal to the negative externalities. Under Pigou's concept, externalities are internalized through taxation.

Coase [5] approached the internalization of externalities from a new angle. He proved a theorem stating that any externality can be internalized through the allocation of property rights. In this case, the inability of the market to factor externalities into prices is circumvented through the allocation of property rights to economic agents with the possibility of their further exchange. Externalities are, therefore, internalized through the allocation of property rights without any further involvement of the state.

The Coase theorem has found its implementation in secondary markets of emissions permits. At the same time, the practical applications of the Coase theorem are limited and the internalization of externalities proves impossible with intervention from the state.

The operation of motor transport involves the use of two major types of public goods: the road network and air. The environment as a pure public good used to be considered non-excludable and non-rivalrous. But with the development of technology, economies have long been facing the problem of a limited carrying capacity of the environment and the need to limit access to this good.

Roads are a pure public good, too, that was also considered non-excludable and non-rivalrous until vehicle ownership rates reached a certain level. Vehicle ownership expansion here is understood as the process of motor vehicle saturation in a certain territory (region). Rising car ownership has aggravated the problem of traffic congestion. Road construction is lagging behind the growing car 
population, while major cities have, for the most part, exhausted their resources for road expansion. The need is ripe for limiting access to this public good as well.

It is possible to conclude that the pure public goods that are used for the operation of car transport are transformed into impure goods as car use increases and remain non-excludable, but become rigorous.

The following instruments are used for the internalisation of externalities generated by transport in Russia:

1) Regulatory tools (for example, a ban on the import of vehicles below the Euro 5 standard that came into force in 2014; technical regulations on the production of vehicles and engine oils).

2) Market instruments (vehicle scrappage fee, fuel duties, environmental impact fee, charge on heavy trucks; parking fee).

Transport tax in Russia is levied on the ownership of vehicles. It is not adapted to the purpose of the internalisation of externalities.

\section{Analysis of negative externalities of motor transport}

The operation of road vehicles produces considerable externalities (both positive and negative ones).

Positive externalities of transport are well known. These include labour mobility, fast shipping of goods, interregional cooperation and holiday and recreation opportunities, which leads to higher labour productivity.

At the same time, negative externalities intensify as vehicle ownership expands. The impact is most prominent in big cities where car use increases spontaneously and people continue to prefer private cars to public transport. In such cities, the negative externalities of motor transport start to outpace the positive ones: traffic speed drops because of congestion; road accident rates go up; drivers are less observant of parking regulations; pedestrian and recreational spaces shrink to allow for bigger roads and parking lots; air quality gets worse and people's general health deteriorates, and so does motorists' mental health.

Table 1 presents the characteristics of the key negative externalities of car use that need to be corrected through transport tax. It has to be noted that the presented externalities are the ones that are most apparent at a higher rate of car ownership when a considerable part of the population of a territory develops strong automobile dependency.

Automobile dependency cripples the lifestyle of the local community, prompting the majority of the community members to use cars when

a) it magnifies negative externalities;

b) it is unnecessary;

c) quality public transport is available as an alternative means of transport. 
Table 1: Characteristics of key negative externalities of excessive automobile use in big cities.

\begin{tabular}{|c|l|l|}
\hline № & Externality & Characteristics of externality uncompensated by car users \\
\hline 1 & Pollution & $\begin{array}{l}\text { Damage caused by exhaust gases, fuel evaporations, particle } \\
\text { pollution; costs of ill-health }\end{array}$ \\
\hline 2 & Traffic jams & $\begin{array}{l}\text { Time lost in traffic jams; additional air emissions in traffic } \\
\text { jams and at lower traffic speeds }\end{array}$ \\
\hline 3 & Road accidents & $\begin{array}{l}\text { Uncompensated damage to involved drivers; time lost by all } \\
\text { travelers; uncompensated higher costs of emergency medical } \\
\text { care and of restoring traffic after collision }\end{array}$ \\
\hline 5 & $\begin{array}{l}\text { More space for } \\
\text { parking }\end{array}$ & $\begin{array}{l}\text { Costs of uncompensated use of pedestrian and recreational } \\
\text { spaces for parking, congested pedestrian and public transport } \\
\text { traffic, esthetic degradation of streets and neighborhoods }\end{array}$ \\
\hline 6 & $\begin{array}{l}\text { More urban } \\
\text { land devoted to }\end{array}$ & $\begin{array}{l}\text { Costs of reallocating land in cities for the sake of road } \\
\text { construction, higher prices of land for housing construction, } \\
\text { higher cost of multi-level interchange projects }\end{array}$ \\
\hline 7 & Road wear & $\begin{array}{l}\text { Costs of building roadside noise barrier; costs of ill-health } \\
\text { and increased irritability }\end{array}$ \\
\hline
\end{tabular}

\section{Negative externality differentiation of territories}

External costs induced by externalities have to vary significantly in absolute terms in different territories. This hypothesis was proven correct in a study by Litman of The Victoria Transport Policy Institute $[6,7]$. His research shows that the average cost (including personal expenses and costs to the community) of a car trip is 0.96 US dollars per mile in rural environments and 1.64 US dollars per mile in urban areas (at 2007 prices). A considerable share of the cost (around 35 percent) are external costs that are not accounted for in vehicle running costs and are not paid by the car owner. These negative externalities (external costs) are paid by the entire community, provided that road construction in the territory is publicly funded.

The external costs will vary in different communities. In rural ones, they will be twice as low in absolute terms as in urban communities. The difference will be bigger, the higher is the road density and car ownership rates in these communities. The greatest costs are seen in bigger cities where car ownership grows at an accelerated pace and the population develops strong car dependency. In this case, transport tax could and should curb demand for private cars.

Three essentially different situations could exist in different areas of a country. They vary in the ration of positive to negative externalities and, consequently, should create different conditions for transport tax, road network development and car ownership constraints (Fig. 1). 


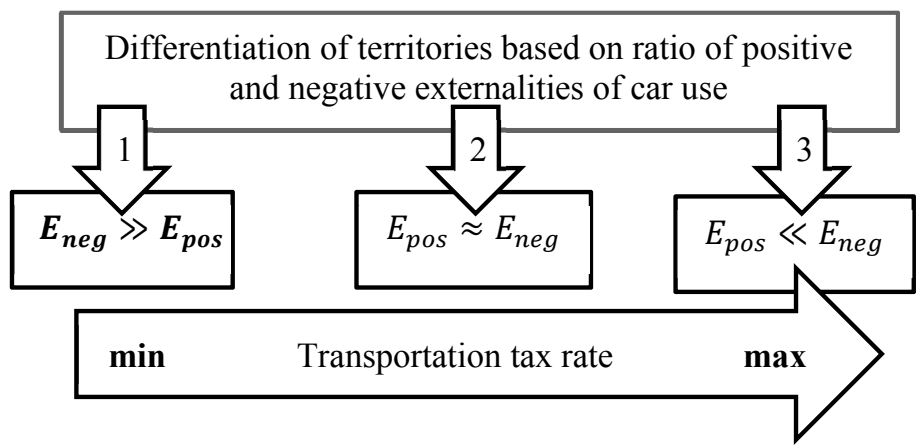

Figure 1: Differentiation of territories based on the ratio of positive $\left(E_{\text {pos }}\right)$ and negative $\left(E_{n e g}\right)$ externalities of car use.

Three typical situations are distinguished here that are essentially different:

1) when the total of positive transport externalities in a territory exceeds the total of negative externalities. The situation is typical of provincial areas that are far from urban agglomerations and district centers and have a low car ownership rate and underdeveloped road infrastructure. A lower transport tax rate in such territories should encourage demand for cars;

2) when the total of positive transport externalities in a territory is approximately equal to the total of negative ones. The situation typically occurs in territories that are close to urban agglomerations and smaller towns and district centers with a medium rate of car ownership and good road infrastructure. The transport tax rate in such territories should encourage neutral consumer attitude to car ownership;

3) when the total of positive transport externalities in a territory is less than the total of negative ones. The situation is typical of big cities and urban agglomerations with a rate of car ownership and a better developed road network. A higher transport tax in such territories should be an instrument for compensation of a majority of negative externalities of car use as well as curb demand for private cars.

\section{Analysis of the transport tax model in Russia}

The Russian model of transport tax has the following specific features:

1) A wide range of means of transport is taxable. There is a specific tax base for each kind of transport (Table 2). At the same time, the overwhelming part of taxable means of transport - over 99 percent - are motor vehicles. Boats and aircraft (including jet-propelled ones) make up slightly over 1 percent of all taxable means of transport. Consequently, taxation is primarily based on engine capacity. 
2) Tax rates are set in roubles per one horsepower of engine capacity. The tax is progressive, with the most notably higher rate progression for automobiles. For example, the tax rate for cars with an engine capacity exceeding $250 \mathrm{hp}$ is six times higher than for cars with an engine capacity up to $100 \mathrm{hp}$, while for trucks the rate is only three times higher. Such approach to rate differentiation takes no account of vehicles' environmental class and does not allow for compensation of negative externalities incurred by the territorial community.

3) Transport tax in Russia is a property tax, i.e., it is related to the ownership of car). Owning a luxury car is subject to a tax markup that could hike the tax rate by up to three times.

4) Transport tax is a regional tax. It is not a target tax and is fully payable to the region. The regions of the Russian Federation can use differentiated tax rates applicable to each category of means of transport (increasing or reducing nationally established tax rates, but not more than tenfold). The regions can also establish differentiate $d$ tax rates with respect to the number of years which have elapsed from the year of manufacture of the means of transport, and (or) their environmental class. The regions are authorized to do so since 2010, but have not used the opportunity yet.

Table 2: Taxable means of transport and tax base.

\begin{tabular}{|l|l|l|}
\hline № & Means of transport & Tax base \\
\hline 1 & $\begin{array}{l}\text { Motorized means of transport (automobiles } \\
\text { and trucks, motorcycles, scooters, buses, } \\
\text { other self-propelled vehicles and pneumatic } \\
\text { and caterpillar machines and mechanisms, } \\
\text { snowmobiles, motor sledges, motor ships, } \\
\text { motor boats, sailing vessels, water scooters, } \\
\text { airplanes and helicopters) }\end{array}$ & $\begin{array}{l}\text { Engine capacity expressed in } \\
\text { horsepowers }\end{array}$ \\
\hline 2 & $\begin{array}{l}\text { Jet aircraft (airplanes) for which the jet } \\
\text { thrust is determined }\end{array}$ & $\begin{array}{l}\text { Certified static take-off thrust } \\
\text { of the jet engine (the } \\
\text { aggregate certified static take- } \\
\text { off thrust of all jet engines) of } \\
\text { the aircraft in terrestrial } \\
\text { conditions in kilogram-force }\end{array}$ \\
\hline 3 & Non-self-propelled (towable) watercraft & $\begin{array}{l}\text { Gross capacity in registered } \\
\text { tonnes }\end{array}$ \\
\hline 4 & Non-motorized watercraft and aircraft & Unit of the means of transport \\
\hline
\end{tabular}

The key advantages and disadvantages of the existing transport tax are outlined below (Table 3 ). 
Table 3: Key advantages and disadvantages of existing model of transport tax.

\begin{tabular}{|c|c|}
\hline Advantages & Disadvantages \\
\hline $\begin{array}{l}\text { 1. Covers a wide range of means } \\
\text { of transport } \\
\text { 2. Unified calculation of tax base, } \\
\text { tax pegged to the time constant } \\
\text { characteristic of engine } \\
\text { capacity } \\
\text { 3ax base easy to control } \\
\text { 4. Possibility of regional rate } \\
\text { differentiation with regard to a } \\
\text { number of factors }\end{array}$ & $\begin{array}{l}\text { 1. Untargeted nature of the tax (i.e., lack of } \\
\text { connection between tax and spending of } \\
\text { collected revenues) enables regions to } \\
\text { use it for purposes other than road } \\
\text { construction and maintenance } \\
\text { 2. Regional nature of the tax makes it } \\
\text { impossible to introduce differentiated } \\
\text { rate for different territorial communities } \\
\text { (municipalities) } \\
\text { 3. Regional nature of the tax stipulates that } \\
\text { all revenue is transferred to the region's } \\
\text { budget, making it impossible for } \\
\text { municipalities to develop their road } \\
\text { network } \\
\text { 4nsufficient regulatory nature of the tax } \\
\text { that does not influence taxpayers' } \\
\text { decision whether to own a car }\end{array}$ \\
\hline
\end{tabular}

\section{Correlation between transport tax rate and key indicators of car use}

The transport tax rate should depend on negative externalities generated by automobiles in a region. At the same time, our analysis does not show that such correlation exists (see Table 4).

As a result, one can conclude that the biggest drawback of the existing transport tax model is that it is in no way related to compensation for the quality and quantity of public goods consumed by car owners. The regions are not inclined to increase the tax rates; there is no logic behind regional rate differentiation.

\section{Goals of transport tax reform}

Transport tax reform should be carried out in Russia with the purpose of enhancing its fiscal function and assign it a regulatory role. At the same time, the tax should retain is nature as a vehicle tax.

The fiscal function of the tax has to be enhance because a low tax rate is an institutional trap. The trap is replicates and sustains itself as a low tax rate results in chronic underfunding of road works, which leads to a lack of balance between the growing number of cars and an unsufficient road network that is increasingly unable to accommodate them. Car owners become ever more unhappy with the quality and amount of roads; their discontent gives rise to opportunistic attitudes to paying a higher transport tax. This creates a vicious circle: car owners are not prepared to pay higher rate tax because roads are bad, while the state is unable to provide them with the required quality and amount of roads because transport tax revenues collected from them are not enough. 
Table 4: Key indicators of car use in some of Russia's regions in 2013.

\begin{tabular}{|l|c|c|c|c|c|}
\hline Region & $\begin{array}{c}\text { Cars per } \\
1,000 \\
\text { population }\end{array}$ & $\begin{array}{c}\text { Transport tax } \\
\text { rate for cars } \\
\text { with engine } \\
\text { capacity } \\
\text { between 100 } \\
\text { and 150 hp RU }\end{array}$ & $\begin{array}{c}\text { Road } \\
\text { density, } \\
\text { km per } \\
10,000 \\
\text { sq. km }\end{array}$ & $\begin{array}{c}\text { Air } \\
\text { pollution } \\
\text { emissions, } \\
\text { thousand } \\
\text { tonnes }\end{array}$ & $\begin{array}{c}\text { Share of } \\
\text { mobile } \\
\text { pollution } \\
\text { sources in } \\
\text { total } \\
\text { emissions, } \\
\%\end{array}$ \\
\hline $\begin{array}{l}\text { Kamchatka } \\
\text { Territory }\end{array}$ & 484.8 & 10 & 4 & 57.8 & 63.9 \\
\hline $\begin{array}{l}\text { Maritime } \\
\text { Territory }\end{array}$ & 369.6 & 20 & 89 & 225.7 & 55.5 \\
\hline Pskov Region & 345.3 & 25 & 281 & 90 & 76.9 \\
\hline Tver Region & 340.5 & 21 & 230 & 135.5 & 69.2 \\
\hline Moscow Region & 330.6 & 29 & 698 & 743.6 & 78.9 \\
\hline $\begin{array}{l}\text { Kaliningrad } \\
\text { Region }\end{array}$ & 330.3 & 14 & 492 & 118.7 & 85.3 \\
\hline $\begin{array}{l}\text { Magadan } \\
\text { Region }\end{array}$ & 330.3 & 8 & 5.2 & 28.1 & 49.2 \\
\hline Moscow & 276 & 35 & 2171 & 929.9 & 93.4 \\
\hline Bryansk Region & 166.6 & 18 & 304 & 72.4 & 66.3 \\
\hline Ingushetia & 130 & 7 & 629 & 27.6 & 97.9 \\
\hline $\begin{array}{l}\text { Chechen } \\
\text { Republic }\end{array}$ & 127.8 & 0 & 480 & 103.7 & 82.9 \\
\hline $\begin{array}{l}\text { Chukotka } \\
\text { Autonomous } \\
\text { Area }\end{array}$ & 73.1 & 7 & 1 & 4.2 & 16.9 \\
\hline
\end{tabular}

A considerable increase in transport tax rates could provide an escape from the trap. But the hike should be differentiated for different territorial communities depending on the rate of car ownership and road density, as well as environmental characteristics of motor transport. And the community itself should be involved in determining the tax rate. The rates should be different not only within the region, because the factors of car and road use might vary drastically in the regional capital and in rural areas. Territorial communities should also be provided with targeted sources of funding for road construction and maintenance.

Transport tax has to have a regulatory role because car ownership cannot grow unchecked. Transport tax must not be neutral to people's investment decisions when buying and owning a car [8]. In one territory it should encourage car ownership, while in the other, on the contrary, the tax should discourage it and create alternative solutions including public transport. The regulatory function can only be fulfilled through a considerable differentiation of rates on the basis of territories as well as on means of transport.

\section{Conceptual model of transport tax}

We consider it expedient to reform transport tax without any radical change to the tax base made up of engine capacity since a state registry has already been created 
and tax administration processes have already been fine-tuned. We suggest that changes should be implemented with regard to tax rates, the nature of the tax and how its elements are managed on different levels. We propose a model of transport tax that contains the following changes to its constituent elements:

1) Transport tax should become a special purpose tax. Revenues from the tax should be accumulated in road funds of regions and municipalities. The use of funds should be restricted to the purposes of environmental protection, road construction and maintenance.

2) The tax base of transport tax should be jointly used by regions and municipalities. The tax rate should, therefore, be split into regional and local components.

3) We propose a multi-tier system for managing fiscal elements of the tax. The rate split and the baseline (minimum) tax rates must be established by the federal government. Regions and municipalities cannot reduce their part of the tax rate, only increase it, but not more than tenfold. They can also introduce incentives on their part of tax.

4) Three adjustment factors could be applied to the regional and municipal components of the transport tax rate: vehicle environmental class, car ownership rate and road density. The adjustment factors can increase as well as decrease the appropriate part of the tax rate. The factors are not applicable to water transport and aircraft.

5) The environmental class factor should adjust the tax rate in proportion to the environmental damage and harm from emissions caused by a specific car. The factor should encourage people to buy cars of a higher environmental class. For example, if the adjustment factor as set at 1 for Euro-5 cars, for Europe- 4 class it could be 1.6, for Euro-3 it could be set at 2.5, at 3.5 for Euro-2 and at 4 for Euro-1.

6) The car ownership factor should adjust transport tax rates with respect to the number of cars in use in a particular area (region or municipality). For example, if the car ownership rate is high (over 300 units per 1,000 inhabitants), a higher adjustment factor of 1.5 should be used to discourage car ownership. If the car ownership level is medium (200 to 300 cars per 1,000 inhabitants), the factor is 1 . For areas with low car ownership, a reduction factor of 0.5 should be applied.

7) The road density factor should adjust transport tax rates, bringing them into line with the development of road infrastructure. Car owners in areas enjoying better roads should pay a higher tax rate, while those with a less developed road network should pay less. For example, if the road density is high (over $500 \mathrm{~km}$ of roads per 10,000 sq. m.), a higher adjustment factor of 1.5 should be applied. For areas with a low road density (less than $200 \mathrm{~km}$ per 10,000 sq. m.), there could be a reduction factor of 0.5 .

\section{Conclusions and research prospects}

Today, transport tax in Russia is fiscally insignificant. It has no influence on people's investment decisions as to whether to own a car. It does not into account 
vehicles' environmental class and provides enough funds for road development in regions and municipalities. As a result, road construction in regions and municipalities is very slow.

In the paper we have proved that in order to escape from this institutional trap transport tax has to be reformed so that its fiscal function enhances and it acquires a regulatory role.

A differentiation system has been substantiated for territories and tax rates depending on a ratio of positive and negative externalities of car use. Economic justifications are provided for transport tax differentiation in territories with different levels of car ownership and road density. The article shows that it is necessary to use an environmental surcharge on transport tax that should encourage car owners to renew their vehicles.

Further research could deal with the development of a quantitative model of transport tax rates for different types of territories and road vehicles. It might also be promising to calculate potential revenues of road funds in a number of regions and municipalities in order to determine the amount of money sufficient for extensive road construction.

\section{References}

[1] Golubeva, A. \& Magaril, E., Improved economic stimulation mechanism to reduce vehicle $\mathrm{CO}_{2}$ emissions. WIT Transactions on the Built Environment, 130, pp. 485-489, 2013.

[2] Magaril, E., Abrzhina, L., Belyaeva, M., Environmental damage from the combustion of fuels: Challenges and methods of economic assessment. WIT Transactions on Ecology and the Environment, 190, VOLUME 2, WIT Press: UK, pp. 1105-1115, 2014.

[3] Mayburov, I. \& Leontyeva, Y. Reducing the negative impact of motor transport on the environment: prospects for the use of fiscal instruments in Russia. WIT Transactions on Ecology and the Environment, 186, WIT Press, UK, pp. 863-874, 2014.

[4] Pigou, A. C. The Economics of Welfare. London: Macmillan and Co. Pub. 896 p., 1920.

[5] Coase, R. The Problem of Social Cost. Journal of Law and Economics. Vol. 3 (1), pp. 1-44, 1960.

[6] Litman, T. Transportation Cost and Benefit Analysis, Victoria Transport Policy Institute, 2007. www.vtpi.org/tca

[7] Litman, T. Using Road Pricing Revenue: Economic Efficiency and Equity Considerations, Transportation Research Record 1558, TRB, pp. 24-28, 1996. www.trb.org

[8] Newbery, David M. \& Santos, G. Road taxes, road user charges and earmarking. Fiscal Studies, Institute for Fiscal Studies. Vol. 20(2), pp. 103$132,1999$. 